\title{
Gambaran Klinis Stomatitis Aftosa Rekuren pada Pasien dengan Infeksi Human Immunodeficiency Virus (Laporan Kasus)
}

\section{Clinical Features Recurrent Aphthous Stomatitis in Patient with Human Immunodeficiency Virus Infection (Case Report)}

\author{
Nurfianti ${ }^{1}$, Siti Aliyah Pradono ${ }^{2}$ \\ ${ }^{1}$ Oral Medicine Residency Program, Faculty of Dentistry, Universitas Indonesia, Jakarta \\ ${ }^{2}$ Department of Oral Medicine, Faculty of Dentistry, Universitas Indonesia, Jakarta \\ E-mail: nurfiantieva@gmail.com
}

KEYWORDS reccurent aphthous stomatitis, HIV, clinical features, tuberculous oral ulcer

ABSTRACT Recurrent oral ulceration usually induced pain and influence patient's quality of life. Reccurent Aphthous Stomatitis (RAS) is a common disorder with recurring ulcers, affecting the oral mucosa, painful and no other signs of systemic disease. Human Immunodeficiency Virus (HIV) is considered as a predisposing factor for RAS. Lesion of RAS associated with HIV, usually more severe, longer lasting to healing and non specific clinical features. This case report describe clinical features of recurrent oral ulceration in HIV patient. A 23 year old female came with complaint oral ulceration in soft palate and tongue since 2 months ago. Patient was diagnosis HIV since seven years ago. Several examinations were done to explore possibility of opportunist infection in HIV patient. Intra oral examination showed regular ulcer, with yellowish base, surrounding erythematous halo. The locations of ulcer were in labial mucosa, dorsum and ventral of the tongue, and soft palate. Ulceration in keratinized mucosa and non keratinized mucosa, gives un-specific features mimicking Tuberculous oral ulcer but in this case there was no indurations on all ulcer. Based on anamnesis and clinical examination, the diagnosis of this case is RAS with differential diagnosis of Tuberculous oral ulcer. The therapy given was gold standard of RAS, the outcome was successful without TB therapy. RAS on HIV Patient can give unspecific clinical features, mimicking oral manifestation of opportunist infection commonly occurred in HIV patient.

PENDAHULUAN

Ulserasi berulang pada rongga mulut seringkali menyakitkan dan dapat mempengaruhi kualitas hidup seseorang (Davoodi et al., 2014). Stomatitis Aftosa
Rekuren (SAR) merupakan suatu gangguan umum yang ditandai ulserasi oral berulang yang terbatas pada mukosa mulut tanpa tanda-tanda lain dari penyakit sistemik. Ulserasi ini umumnya terdapat pada mukosa tidak berkeratin. 
Defisiensi hematologi, gangguan kekebalan tubuh, dan penyakit jaringan ikat dapat menyebabkan ulserasi yang secara klinis mirip dengan SAR, yang dapat diatasi apabila kondisi sistemiknya dilakukan penatalaksanaan yang komprehensif (Woo et al., 2015; Preeti et al, 2011).

Stomatitis Aftosa Rekuren merupakan penyakit kronik yang mempengaruhi $20 \%$ dari populasi dunia (Woo et al., 2015; Hudson, 2014). Usia onset SAR dari masa kanak-kanak atau remaja, antara usia 10-19 tahun dan biasanya diderita sampai dewasa bahkan dapat seumur hidup, ditandai dengan ulserasi oral beulang yang menyakitkan lebih banyak kemungkinan terpapar pada perempuan dan individu dengan tingkat sosial ekonomi yang lebih tinggi (Belenguer-Guallar et al., 2014; Akkoca et al., 2014; Brocklehurst et al., 2012). Gejala prodromal biasanya ditandai dengan rasa terbakar ataupun sakit pada 24-48 jam, kemudian terjadi ulserasi (Scully et al., 2013).

Faktor predisposisi dari SAR, adalah stres, faktor genetik, defisiensi hematologi (kekurangan zat besi, asam folat atau vitamin B12), kelainan imunologi, faktor-faktor lokal, seperti trauma, alergi makanan dan pasta gigi yang mengandung Sodium lauryl sulfate (Woo et al., 2015; Hudson, 2014; Caputo, 2012) Infeksi HIV dianggap sebagai faktor predisposisi untuk SAR terkait defisiensi imun. Lesi SAR terkait HIV cenderung lebih parah dan lebih lama penyembuhannya serta rasa nyeri yang megganggu fungsi berbicara, mengunyah, dan menelan, yang pada akhirnya dapat terjadi kekurangan gizi, dan penurunan berat badan, kesulitan dalam menelan obat-obatan, sehingga mengganggu kualitas hidup (Caputo, 2012). Diagnosis dini diperlukan untuk mendapatkan penataksanaan yang optimal sehingga dapat meningkatkan kualitas hidup pasien dengan infeksi HIV (Coogan, 2005) .

Pada laporan kasus ini akan dibahas suatu kasus, seorang dengan riwayat ulserasi oral berulang yang terjadi setelah terdiagnosis HIV.

\section{METODOLOGI DAN ISI}

\section{Laporan Kasus}

Seorang wanita, berusia 23 tahun datang ke Poli Penyakit Mulut RSCM dengan keluhan sariawan di lidah dan langit-langit sejak dua bulan lalu. Sariawan telah diterapi oleh beberapa dokter gigi, tetapi tidak ada penyembuhan dan masih terasa sakit. Satu minggu lalu, pasien dirawat di rumah sakit selama 7 hari, karena kesulitan menelan, makan, dan minum. Selama dirawat, sariawannya diobati dengan Nistatin suspensi oral, Fluconazol dan Kotrimoksazol, tetapi pasien tidak merasa ada perbaikan. Pasien memiliki riwayat medis infeksi HIV sejak tujuh tahun yang lalu, telah diterapi dengan Anti Retroviral Therapy, Duviral dan Efavirenz. Hasil pemeriksaan enam bulan yang lalu, jumlah sel CD4 sebanyak 3 sel /uL, viral load belum pernah dilakukan pemeriksaan. Riwayat sariawan berulang sejak didiagnosis infeksi HIV. Sariawan berpindah-pindah lokasi, tidak ada demam sebelum muncul sariawan, penyembuhan sariawan biasanya dalam satu bulan. Pada pemeriksaan ekstra oral, bibir kering, tidak terdapat pembesaran pada kelenjar getah bening servikal. Pemeriksaan Intra Oral, terdapat ulser reguler dasar putih tepi halo eritema, tidak terdapat indurasi pada mukosa labial bawah (ukuran 7 × $5 \mathrm{~mm}$ ), dorsum lidah (ukuran $10 \times 3 \mathrm{~mm}$ ), ventral lidah 
(ukuran 5 x $2 \mathrm{~mm}$ ). Pada palatum mole, terdapat ulser, dasar putih kekuningan, tepi halo eritema, tidak terdapat indurasi ukuran 20 x 15 mm. (Gambar 1). Berdasarkan anamnesis dan pemeriksaan klinis, diagnosis kasus ini adalah Stomatitis Aphthous Rekuren (SAR) Terapi yang diberikan kumur buang Doxycyclin 100mg, 3 kali sehari dan vitamin yang meliputi vitamin Bkompleks, vitamin $\mathrm{C}$ dan zinc, satu kali sehari. Pasien dirujuk ke Kelompok Kerja AIDS (Pokdisus AIDS FKUI / RSCM) untuk kelanjutan terapi infeksi HIV, investigasi viral load, dan pemeriksaan darah perifer lengkap.

Kunjungan berikutnya ( 2 minggu dari kunjungan pertama ), pasien dikonsul dari Kelompok Kerja AIDS (Pokdisus AIDS FKUI / RSCM) untuk dilakukan biopsi ulserasi oral, yang diduga Ulser Oral Tuberkulosis. Hasil pemeriksaan darah lengkap menunjukkan rendahnya kadar hemoglobin, hematokrit, eritrosit dan jumlah leukosit, dan peningkatan jumlah trombosit dan laju endap darah. Skrining HIV reaktif, dengan jumlah CD4 $10 \mathrm{sel} / \mathrm{mm}^{3}$. Berdasarkan anamnesis, pasien rasa sakit pada sariawan berkurang, dan sudah dapat makan makanan padat. Pemeriksaan intra oral terlihat penyembuhan pada ulser di mukosa labial dan dorsum lidah. Ulserasi pada palatum molle tidak terlihat berkurangya ukuran lesi hanya sudah berkurang rasa nyeri pada ulser (Gambar 2).
Berdasarkan anamnesis dan gambaran klinis, didiagnosis SAR dengan diagnosis banding Ulser Oral Tuberkulosis. Penatalaksaanaan ulser dengan obat kumur yang mengandung polivinilpirolidon (PVP), asam glycyrrhetinic, ekstrak lidah buaya, dan sodium hyaluronate, empat kali per hari, serta suportif berupa vitamin yang mengandung vitamin B-kompleks, vitamin $\mathrm{C}$ dan seng, dan nutrisi makanan. Setelah lebih dari satu bulan dari kunjungan pertama, pasien mengatakan ulserasi di palatum molle telah sembuh. Biopsi belum dapat dilakukan karena kondisi pasien tidak memungkinkan dilakukan tindakan invasif. Pemeriksaan Venereal Desease Research Laboratory (VDRL) dan Treponema Pallidum Hemaglutination Assay (TPHA), Anti Herpes Simplex Virus (HSV) I dan II, Anti Hepatitis $C$ Virus (HCV), Hepatitis $B$ Surface Antigen (HbsAg), pemeriksaan radiologi dilakukan untuk mengetahui kemungkinan infeksi oportunis yang dapat terjadi pada pasien HIV. Hasil pemeriksaan VDRL dan TPHA non reaktif, Anti HSV I dan II Ig M non reaktif, Anti HCV non reaktif, dan HBsAg reaktif. Pemeriksaan radiologi, tidak ditemukan tanda-tanda abnormal pada jantung dan paru-paru. Viral load 3,190 kopi / mL. Pemeriksaan intra oral, tidak ditemukan ulkus pada palatum molle (Gambar 3). Penegakkan diagnosis pada kasus ini adalah SAR dengan faktor predisposisi infeksi HIV. 

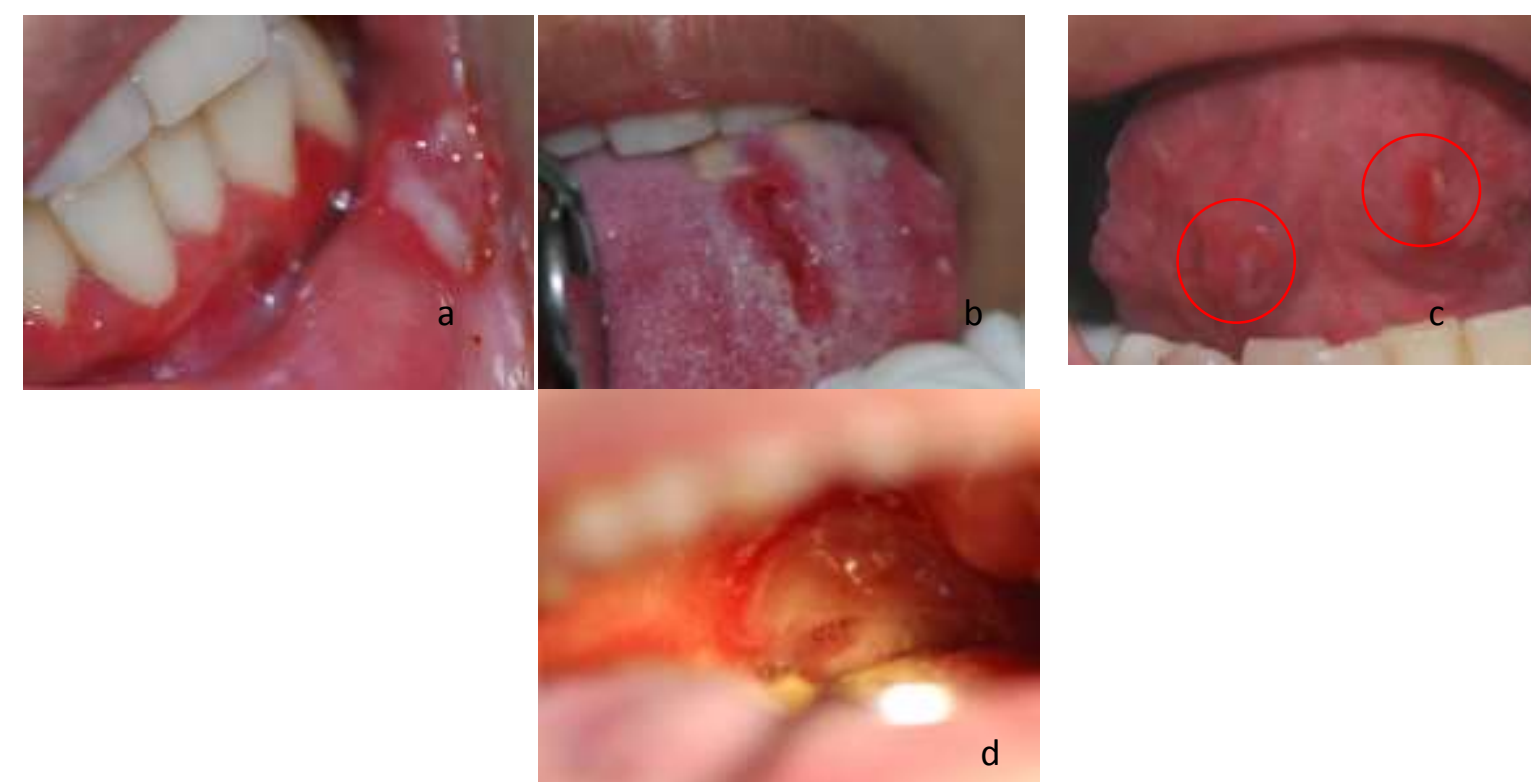

Gambar 1. Ulser reguler dasar putih tepi halo eritema pada mukosa labial bawah (a), dorsum lidah (b), dan ventral lidah (c). Pada palatum mole, terdapat ulser, dasar putih kekuningan, tepi halo eritema (d)
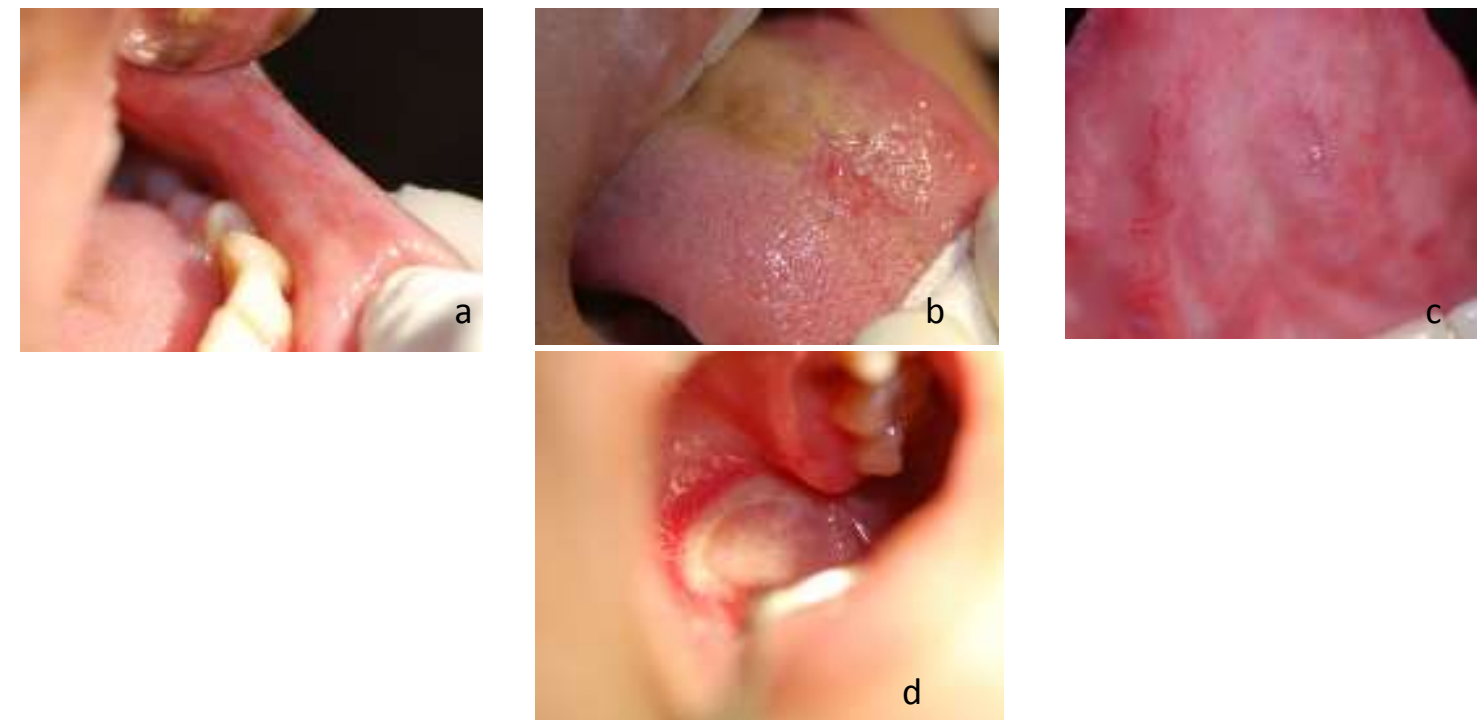

Gambar 2. Perbaikan ulser reguler pada mukosa labial bawah (a), dan dorsum lidah (b). Tidak terdapat ulser pada ventral lidah (c). Pada palatum mole, masih terdapat ulser, dasar putih kekuningan, tepi halo eritema (d)

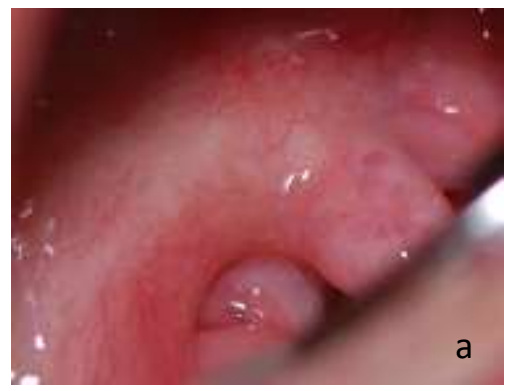

Gambar 3.Palatum mole tanpa adanya ulserasi(a) 
Ulserasi pada pasien dengan infeksi HIV cenderung lebih parah dan lebih lama penyembuhannya serta rasa sakit yang mengganggu fungsi berbicara, mengunyah, dan menelan, yang pada akhirnya dapat terjadi kekurangan gizi, dan penurunan berat badan, kesulitan dalam menelan obat-obatan (Caputo, 2012). Pada pasien non-HIV/AIDS ulserasi oral berulang dapat menyembuh tanpa pengobatan. Pada infeksi HIV/AIDS, ulserasi biasanya disertai infeksi sekunder dan mengandung jaringan nekrotik, dengan tepi ulserasi tidak teratur dikelilingi halo eritema dan rasa nyeri yang parah, serta membutuhkan waktu lama untuk proses penyembuhan (Brocklehurst et al., 2012). Penegakkan diagnosis SAR berdasarkan anamnesis pasien tentang riwayat ulserasi dan gambaran klinis. Pemeriksaan histopatologi dilakukan untuk menyingkirkan diagnosis banding dari SAR (Akkoca et al., 2014; Caputo, 2012). Klasifikasi dari SAR berdasarkan gambaran klinis terdiri dari aftosa minor, aftosa mayor dan aftosa herpetiform (Tabel 3) (Woo et al., 2015; Hudson, 2014; Caputo, 2012).

Manifestasi oral SAR pada seseorang dengan infeksi HIV memiliki prevalensi sekitar 2-3\% (Gnanasundaram, 2010). Gambaran klinis dari SAR pada pasien dengan infeksi HIV biasanya berupa aftosa mayor yang parah, dengan lokasi yang terbanyak dilaporkan pada palatum molle, tonsil, dan lidah. Meskipun ada banyak pasien dengan riwayat SAR dari sejak kecil, yang menjadi lebih parah setelah infeksi HIV. Pasien yang sebelumnya tidak memiliki riwayat SAR, kemudian setelah terkena infeksi HIV baru muncul SAR, dikarenakan kurangnya jumlah limfosit dianggap sebagai etiologi dari hipotesis terjadinya lesi. Berdasarkan penelitian SAR pada HIV berhubungan dengan menurunnya CD4 dan meningkatnya viral load (Miziara, 2005). Ulserasi yang parah berupa mayor aftosa biasanya terjadi pada pasien dengan CD4 $<100 \mathrm{sel} / \mathrm{mm}^{3}$ (Chapple, 2000) Pada penyakit infeksi HIV terjadi perubahan sistem kekebalan tubuh yang ditandai perubahan rasio CD4 dan CD8, dengan penurunan jumlah CD4. Peningkatan molekul adhesi dan sitokin (ICAM-I dan Elam) dan produksi $\mathrm{TNF} \alpha$ dalam limfosit di peredaran darah perifer, juga berperan dalam patogenesis SAR (Woo et al., 2015; Phail, 1992).

Ulser oral Tuberkulosis (TB) dijadikan diagnosis banding, dikarenakan adanya ulserasi pada dorsum lidah yang merupakan mukosa tidak berkeratin dan ulser pada palatum dengan respon yang lama terhadap terapi. Lokasi kedua ulser juga merupakan lokasi yang sering ditemukannya ulser oral TB. Gambaran klinis ulser di dorsum lidah dan palatum menyerupai ulser oral TB sekunder, hanya pada ulser tersebut tidak terdapat

Tabel 1. Kareteristik Gambaran Klinis SAR

\begin{tabular}{lccc}
\hline \multirow{2}{*}{ Karateristik } & \multicolumn{3}{c}{ Gamnbaran klinis } \\
\cline { 2 - 4 } & Aftosa Minor & Aftosa Mayor & Aftosa Herpetiform \\
\hline Ukuran (mm) & $5-10$ & $>10$ & $<5$ \\
Durasi (hari) & $4-14$ & $20-30$ & 15 \\
Jaringan parut & Tidak & Ada & Tidak \\
Presentasi dari semua aftosa & $75-85$ & $10-15$ & $1-10$ \\
\hline
\end{tabular}


indurasi. Ulser oral TB adalah relatif jarang, memiliki prevalensi kurang dari satu persen dari populasi dengan tuberkulosis. Lesi tuberkulosis oral mungkin primer atau sekunder, tetapi lesi primer jarang terjadi biasanya pada pasien usia muda dengan ulser tunggal yang menyakitkan, terdapat indurasi disertai dengan pembesaran kelenjar getah bening. Lesi sekunder, umumnya terjadi dengan ulser tunggal, indurasi, tepi lesi tidak teratur, nyeri, ulser ditutupi oleh eksudat inflamasi pada biasa terjadi pada pasien kelompok usia pertengahan dan usia tua (Jain et al., 2014; Dixit et al., 2008).

Penegakkan diagnosis definitif ulser oral TB melalui biopsi eksisi jaringan dan pemeriksaan kultur bakteri. Pada gambaran histopatologi pada terlihat adanya caseating granuloma yang terdiri dari sel epitel dan giant cells (Langhans giant cells). Berdasarkan beberapa penelitian hanya sebagian kecil $(7,8 \%)$ positif terhadap pewarnaan basil tahan asam, bila hasil negatif tidak menutup kemungkinan TB. Pemeriksaan klinis, radiologi, histopatologi memainkan bagian penting dalam diagnosis TB (Jain et al., 2014). Pada pasien ini tidak dapat dilakukan pemeriksaan histopatologi karena kondisi sistemik yang tidak memungkinkan untuk dilakukan tindakan invasif. Pada pemeriksaan radiologi tidak ditemukan tanda-tanda abnormal pada jantung dan paru-paru.

Penatalaksanaan SAR pada pasien HIV bertujuan untuk mengurangi rasa sakit, menurunkan durasi ulserasi, dan mencegah infeksi sekunder (Caputo, 2012). Pada kasus ini pasien diberikan kumur buang Doksisiklin dengan tujuan efek antibakteri, mengurangi kerusakan kolagen oleh aktivitas kolagenase (anti kolagenase), menghambat gelatinase, dan menghambat produksi prostaglandin, serta menekan aktivitas leukosit (Woo et al., 2015; Gorsky, 2007; Vijayabala, 2013). Kolagenase interstitial (MMP-1 dan MMP-8) adalah enzim-enzim mendegradasi kolagen tipe mukosa mulut yang berperan dalam kerusakan jaringan di SAR. Gorsky dkk., melakukan uji coba kumur buang doksisiklin dapat mengurangi rasa sakit, mengurangi keparahan dan durasi ulser. Denman dan Schiff juga melaporkan kumur buang tetrasiklin hidroklorida, dapat mengurangi rasa sakit dan frekuensi SAR (Vijayabala, 2013).

Pengurangan rasa nyeri pada pasien SAR juga dapat diatasi dengan aplikasi asam hialuronat. Efek lainnya berupa mempercepat penyembuhan jaringan dengan meningkatkan epitelisasi melalui proliferasi sel keratinosit basal, meningkatkan angiogenesis, dan mengontrol hidrasi jaringan selama proses inflamasi. Pemberian aloe vera digunakan untuk penyembuhan luka, anti-infeksi anti-inflamasi, dapat mengurangi rasa nyeri dari lesi SAR, dan juga bersifat antioksidan. Asam glycyrrhetinic juga digunakan dalam penataksanaan kasus ini, sebagai antiinflamasi yang membantu dalam penyembuhan ulser. Polyvinylpyrolidone dalam terapi sebagai muco-aderen dan membentuk lapisan film, yang dapat meningkatkan hidrasi jaringan. Keempat bahan diatas bekerja bersamaan sehingga dapat mengurangi rasa sakit dan kesulitan dalam menelan makanan padat dan cairan, dan aman untuk digunakan pada bayi dan anak-anak (Babaee et al., 2012; Cimaz, 2002; Kapoor et al., 2011).

Pengobatan SAR masih menjadi tantangan besar terutama pada pasien imunokompromais, yang memerlukan penatalaksanaan secara komprehensif. Pada kasus ini terlihat adanya respon 
yang lambat dari terapi yang dtelah diberikan terutama pada ulser mayor yang terdapat di palatum molle. Memerlukan waktu lebih dari satu bulan untuk penyembuhan ulser. Penanganan kasus ini juga bekerjasama dengan berbagai disiplin ilmu, karena perbaikan sistemik pasien menentukan keberhasilan perawatan ulserasi oral.

Pada kasus ini diagnosis definitif SAR, usia pasien pertama kali muncul SAR masih dalam usia onset SAR yaitu 16 tahun, dengan faktor predisposisi dari kasus ini yaitu jumlah CD 4 yang rendah $10 \mathrm{sel} / \mathrm{mm}^{3}$ dan adanya anemia. Gambaran klinis ulserasi menunjukkan karateristik SAR tipe mayor dengan ulserasi regular, dikelilingi halo eritematosa, dasar lesi putih kekuningan, dan tidak adanya indurasi. Keunikan dari kasus ini adalah gambaran ulserasi pada dorsum lidah, hal ini berbeda dengan gambaran SAR pada umumnya yaitu pada mukosa tidak berkeratin. Ulser pada kasus ini juga memperlihatkan adanya penyembuhan dengan terapi sesuai dengan terapi SAR, tanpa terapi Tuberkulosis.

\section{PENUTUP}

SAR pada pasien HIV dapat memberikan gambaran klinis yang tidak spesifik, menyerupai manifestasi oral infeksi oportunistik yang biasanya terjadi pada infeksi HIV.

\section{Ucapan Terima Kasih}

Kami mengucapkan terima kasih kepada drg. Endah Ayu Sp.PM selaku supervisor Poli Penyakit Mulut RSCM dan teman-teman PPDGS IPM angkatan 2012, 2013 dan 2014 atas dukungan semangatnya.

\section{DAFTAR PUSTAKA}

Akkoca, A.N., Özdemir, Z.T., Yanık, S., Arıca, S.G., Yalçin, H., Özler, G.S. 2014. The frequency and etiology of recurrent apthous stomatitis in helicobacter pylori positıve patients. Am J Intern Med.;2(4):72-8.

Babaee, N., Zabihi, E., Mohseni. S., Moghadamnia, A. 2012. Evaluation of the therapeutic effects of Aloe vera gel on minor recurrent aphthous stomatitis. Dent Res J.;9(4):381-5.

Belenguer-Guallar, I., Jiménez-Soriano, Y., Claramunt-Lozano, A. 2014. Treatment of recurrent aphthous stomatitis. A literature review. J Clin Exp Dent. 6(2):e168-74.

Brocklehurs,t P., Tickle, M., Glenny, A.,M., Lewis, M., Pemberton, M.N., Taylor, J., 2012. Systemic interventions for recurrent aphthous stomatitis (mouth ulcers). Cochrane database Syst Rev. 9(9):1-7.

Caputo, B.V., Noro, Filho, G.A., Dos Santos, C.C., Okida, Y., Giovani, E.M. 2012. Laser Therapy of Recurrent Aphthous Ulcer in Patient with HIV Infection. Case Rep Med.:1-3.

Chapple, I.L., Hamburger, J. 2000. The significance of oral health in HIV disease. Sex Transm Infect. 76(4):236-43.

Cimaz, I.R. 2002. Safety and Efficacy of Aloclair ${ }^{\mathrm{TM}} \mathrm{Gel}$ in the treatment of Oral Aphthous Lesions in Children: Preliminary Findings from an Open Pilot Study. Aloclair Gel Trial.;(March):1-6. 
Coogan, M.M., Greenspan, J., Challacombe, S.J. 2005. Oral lesions in infection with human immunodeficiency virus. World Heal Organ Bull World Heal Organ. 83(9):700-6.

Davoodi, P., Hamian, M., Nourbaksh, R., Ahmadi Motamayel, F. 2010. Oral Manifestations Related To CD4 Lymphocyte Count in HIVPositive Patients. J Dent Res Dent Clin Dent Prospects. 4(4):115-9.

Dixit, R., Sharma, S., Nuwal, P. 2008. Tuberculosis of Oral Cavity. Indian J Tuberc. 55:51-3.

Gnanasundaram, N. Key to Diagnose HIV / AIDS Clinically through its Oral Manifestations. J Indian Acad Oral Med Radiol.2010;22:119-25.

Gorsky, M.B.E.J, 2007. Topical minocycline and tetracycline rinses in treatment of recurrent aphthous stomatitis: a randomized cross-over study. Dermatology online. 13(2).

Hudson. J. 2014. Recurrent Aphthous Stomatitis : Diagnosis and Management in Primary Care Recurrent Aphthous Stomatitis: Diagnosis and Management in. $\mathbf{J}$ Patient-Centered Res Rev. 1(4):197-200.

Jain. P, Jain. I. 2014. Oral Manifestations of Tuberculosis: Step towards Early Diagnosis. Journa Clin Diagnostic Res. 8(12):18-21.
Kapoor, P., Sachdeva, S., Sachdeva, S. 2011. Topical Hyaluronic Acid in The Management of Oral Ulcers. Indian J Dermatol. 56(3):300-2.

Miziara, I.D., Araujo Filho, B.C,, Weber, R. 2005. AIDS and Recurrent Aphthous Stomatitis. Braz J Otorhinolaryngol.71(4):517-20.

Phail, M. S.J G. 1997. Oral ulceration in HIV infection: investigation and pathogenesis. UCSF Dept Stomatol. 3(1):190-3.

Preeti, L., Magesh, K., Rajkumar, K., Karthik, R. 2011. Recurrent aphthous stomatitis. J Oral Maxillofac Pathol. 15(3):252-6.

Scully, C., Gorsky, M., Lozada-Nur, F. 2003. The diagnosis and management of recurrent aphthous stomatitis: a consensus approach. J Am Dent Assoc. 134(2):200-7.

Vijayabala, G.S., Kalappanavar, A., Annigeri, R., Sudarshan, R., Shettar, S. 2013. Single application of topical doxycycline hyclate in the management of recurrent aphthous stomatitis. Oral Surg Oral Med Oral Pathol Oral Radiol. 2013;16(4):440-6.

Woo, S.B., Greenberg, M.S. 2015. Burket's Oral Medicine. 12th ed. Glick M, editor. Connecticut: People's Medical Publishing House-USA.173-182. 